303. 田村善蔵, 松島美一：脂肪族ポリカルボン酸のカルシウム扔よび ストロンチウム錯化合物に関する研究

Zenzo Tamura and Yoshikazu Matsushima: Studies on the Complexes of Calcium and Strontium with Some Aliphatic Polycarboxylic Acids.

(Faculty of Pharmaceutical Sciences, University of Tokyo*)

As an agent accelerating excretion of radioisotopic strontium that has entered a living body, tricarballylic acid, 1,1,2,3-propanetetracarboxylic acid, and 1,2,3,4-butanetetracarboxylic acid were prepared, and stability constants were calculated for the complexes formed between these acids with calcium and strontium. The measurement was carried out by the method using ion exchange resin, initiated by Schubert, at $\mu=0.156,25^{\circ}$. Results thereby obtained are listed in Table I.

(Received May 22, 1959)

生体内に侵入した放射性ストロソチウムの排泄促進のために，ストロンチウムと錯化合物生成の能力を有する 化合物のあるものが有効であることがすでに協同研究者によつて報告されている1).さらに有効なる藥剤探求のた めには排泄促進剤がカルシウム特よびストロンチウムと形成する錯化合物の安定度定数を知る必要がある2)ので,

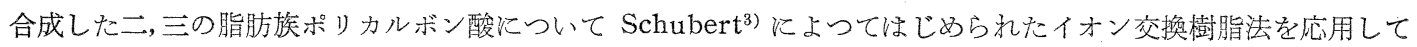
測定を試みた。その原理はつざの如くである.

金属イオン $\mathrm{M}$ と有機酸イオン $\mathrm{A}$ との間に錯化合物 MAn が形成されるとき (1) 式の如き平衡が成立する.

$$
\mathrm{M}+n \mathrm{~A} \rightleftharpoons \mathrm{MA} n
$$

この錯化合物の安定度定数 $K$ は (2) 式で示される。

$$
K=\frac{[\mathrm{MAn}]}{[\mathrm{M}][\mathrm{A}]^{r}}
$$

濃度〔A]の有機酸イオンと金属イオン $\mathrm{M}$ を含も溶液に陽イオン交換樹脂を共存させた場合, 金属イオン $\mathrm{M}$ は樹脂・溶液間に分配される，その分配率を $K d$, 特に [A]が 0 に等しい場合の分配率を $K d^{0}$ とする. Schubert $^{3)}$ によれば M. の濃度がイオン交換樹脂の交換容量に比し充分小なる場合には (3) 式が成立する。

$$
K=\frac{\left(K d / K d^{0}\right)-1}{[\mathrm{~A}]^{n}}
$$

$K d, K d^{0}$ は測定可能の值でめり，数種の異なつた〔A]についての測定值より $n$ を求めることができる. 式の右辺はすべて測定可能であるので，この式より $K$ を求めることができる.

著者等は金属イオンとして carrier-free の放射性カルシウム拉よびストロンチウムを用いて Schubert ${ }^{3)}$ の理 論により $K$ を求めた.

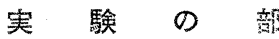

\section{(1) 有機酸の合成*1}

測定に用いた有機酸ほつぎの如くにして合成した。

Tricarballylic Acid Org. Syntheses ${ }^{4}$ 記載の方法により tetraethy1 1,1,2,3-propanetetracarboxylate (b $\left.\mathrm{b}_{12} 194 \sim 197^{\circ}\right)$ を経て合成した。水上り再結晶, $\mathrm{mp} 160^{\circ}$.

1,1,2,3-Propanetetracarboxylic Acid 前記の如くして得た tetraethyl 1,1,2,3-propanetetracarboxylate

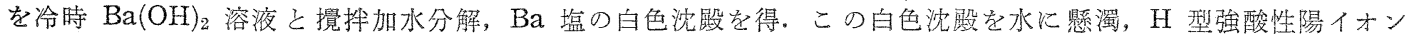

* Motofuji-cho, Bunkyo-ku, Tokyo.

1) Y. Ito, S. Tsurufuji, S. Ishibashi, M. Ishidate, Z. Tamura : Pharm. Bull. (Tokyo) 6, 34(1958);

Y. Ito, S. Tsurufuji, E. Murai, S. Ishibashi, M. Ishidate, Z. Tamura: Ibid. 6, 92(1958).

2) Y. Ito, S. Tsurufuji, M. Shikita, S. Ishibashi : Ibid. 6, 287(1958).

3) J. Schubert: J. Phys. Chem. 56, 113(1952). *1融点は未補正。

4) 邦訳 Org. Syntheses: Col. Vol. 1, 289, 569(1935). 
交換樹脂 Amberlite IR-120 とバッチ法にて混合靦挥，澄明な液を得．樹脂を沪別，沪液を減圧乾固・得られた白

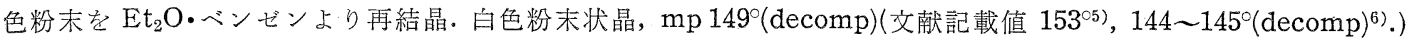

1,2,3,4-Butanetetracarboxylic Acid Auwers 等7)の方法により pentaethy1 1,1,2,3,4-butanepentacarboxylate $\left(\mathrm{bp}_{0.3} 1^{\circ}\right)$ を経て meso 型8) 1,2,3,4-butanetetracarboxylic acid (AcOH より再結晶, 白色粉 末状晶, $\mathrm{mp} 190^{\circ}$, 文献記載值 $189^{\circ 7}$ ) 拈よび $d l$ 型8) 1,2,3,4-butanetetracarboxylic acid (水より再結晶, 白 色粉末状晶, mp $237^{\circ}$, 文献記載值 $236^{\circ 7)}$ ) を合成した。

\section{(2) 安定度定数の測定}

装置恒温水槽 (温度 $25 \pm 0.2^{\circ}$ ) 中に共栓ガラス容器 12 個を入れられるバスケットを装置し, それをモ 一タ一で水平に振盪できるようにし恒温振盪装置とした。 pH 測定は東亜電波工業 KK HM-3 型ガラス電極 $\mathrm{pH}$ 計を用い，放射線計測には科研 $\mathrm{GM}$ 計数管を用いて行なつた。

試薬金属イオン溶液は carrier-free ${ }^{45} \mathrm{Ca}$ をたは ${ }^{90} \mathrm{Sr}$ を $0.1 N \mathrm{HC} 1$ に溶解したものを用いた。有機酸 溶液は上記の如く合成した有機酸を $\mathrm{Na}$ 塩とし $0.001 \sim 0.002 M$ 溶液とした。 $0.16 M \mathrm{NaCl}$ 溶液, $0.4 M \mathrm{Na}$ diethylbarbiturate 溶液，有機酸溶液はいずれも使用直前に脱炭酸蒸留水を用いて調製， NaCl を加えてイオン 強度が 0.16 になるようにした。

陽イオン交換樹脂は Amberlite IR-120 の 60〜100 mesh のものを充分 conditioning した後，Na 型とし風

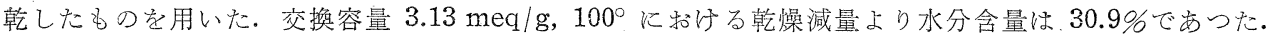

操 作 共栓方ラス容器中に陽イオン交換樹脂, carrier-free ${ }^{45} \mathrm{Ca}$ 屯た ${ }^{90} \mathrm{Sr} の 0.1 N \mathrm{HCl}$ 溶液 $1 \mathrm{cc}$, $\mathrm{NaCl}$ 溶液, 有機酸溶液を混合, $\mathrm{Na}$ diethylbarbiturate 溶液を加え $\mathrm{pH}$ を 7 付近に調節かつ緩衝作用を持た せた。溶液の最終液量は $50 \mathrm{ml}$, イオン強度は 0.156. この混合液を入れたガラス容器を恒温振盪装置で約 20 時 間振盪, 平衡に達せしめた後上液 $1 \mathrm{cc}$ を樹脂が混入せぬよう注意しつつ金属ペトリ皿に採り, 赤外ランプによ り乾燥, 測定試料とした. ${ }^{45} \mathrm{Ca}$ の場合は任意の時, ${ }^{90} \mathrm{Sr}$ の場合は試料作製より25日以上経過せしめた後，計数 した (Table III 参照).

実験条件の検討 計数值と $\mathrm{Ca}$ なた $\mathrm{Sr}$ 量：試料作製時にアイソトープ含有液採取液量を $0.2,0.4, \ldots$ . $1 \mathrm{cc}$ と変化させたものについて試料計数值を比較したところ，採取液量と計数值は比例した。故に実験に用い た箸团で核計数值と $\mathrm{Ca}$ 屯たは $\mathrm{Sr}$ 量は直線的に比例する.

器壁への同位元素の吸着：実験の一部について，平衡に達した後の陽イオン交換樹脂を分離，吸着せる放射 性同位元素を dil $\mathrm{HCl}$ 飞て溶離, 溶離液の一部学採り計測, 上液の計測值と比較, 容器器壁等への放射性同位 元素の吸着が無視し得るものであることを確かめた。

$K d^{0}$ の一定なること： 液量, 樹脂量等を種々に変化せしめて $K d^{0}$ を測定, $K d^{0}$ がそれらにより変化しない ことを確認した.

Diethylbarbiturate の錯化合物生成能：“緩衝剂として用いた diethylbarbiturate が $\mathrm{Ca}, \mathrm{Sr}$ と錯化合物を 形成する場合は測定が障害される. diethylbarbiturateの濃度を種々に変化せしめて测定，実験に用いた範囲で は錯化合物を形成しないことを確認した。

\section{結果および考察}

測定值から得られた各化合物の錯化合物生成此抢よび安定度定数を Table I に示す。また Table I を得る過 程を meso 型 1,2,3,4-butanetetracarboxylic acid について Table II 抢よび Fig. 1 に例示した.

tricarballylic acid は Table I の結果からほ有効と思われるが，実際この化合物は生物試験で有效なること が認められている1). tricarballylic acidの $\alpha$ 位の炭素にカルボキシル基がさらに 1 つ加わり，1,1,2,3-propanetetracarboxylic acid になると安定度定数がカルシウム，ストロソチウム共增加しかつ近接する・このことより この化合物も有望と思われるが，生物試験でもある程度有効なることが認められている9.

$d l$ 型 1,2,3,4-butanetetracarboxylic acid はカルシウムとは実験に用いた濃度籁囲 0.0005〜0.004M, pH 7.1 飞持いては鏡化合物の形成を認めることができなかつた、ストロンチウムについては濃度範囲 0.0004〜0.003M に括いて明らかに錯化合物を形成したが，実験誤差の大なることと，生成比が不詳のため定数を求めることがで きなかつたが，酸１分子に対し２原子のストロンチウムが結合する能力が出るように思われる.

カルシウムとストロンチウムの錯塩安定度定数の関係を逆転させることは困難であるが，この系列の化合物の 中からストロンチウム排泄剤としてより有效な化合物を求めることは可能と思われる。

5) A. Michaelis, J. Ross: J. Am. Chem. Soc. 53, 1163(1931).

6) R. D. Haworth, L. B. de Silva: J. Chem. Soc. 1954, 3615.

7) K. Auwers, A. Jacob : Ber. 27, 1114(1894).

8) K. Alder, M. Schumacher : Ann. 564, 96(1949).

9) 伊藤, 鶴藤, 色田, 石橋, 石舘, 田村, 松島: 日本薬学会関東支部例会発表 (1958 年 2 月 22 日). 
Table I. Stability Constants of Complexes

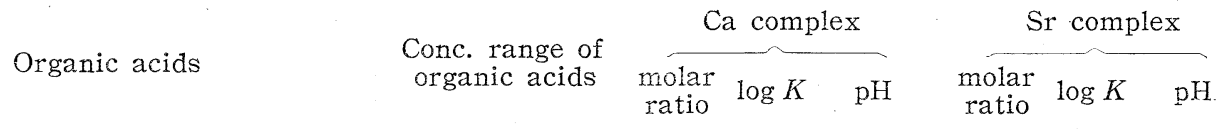

Tricarballylic acid<smiles>O=C(O)CC(CC(=O)O)C(=O)O</smiles>

$\begin{array}{lllllll}0.001 \sim 0.008 & 1: 1 & 1.62 & 6.2 \sim 6.7 & 1: 1 & 1.16 & 7.2\end{array}$

$(0.002 \sim 0.02 \quad 1: 1 \quad 1.82 \quad 7.2 \sim 7.3 \quad 1: 1 \quad 1.68 \quad 7.2 \sim 7.3)$ *

1,1,2,3-Propanetetracarboxylic acid

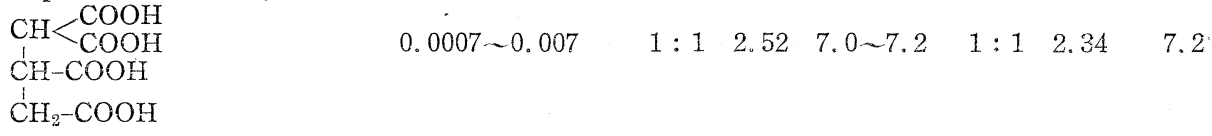

meso-1,2,3,4-Butanetetracarboxylic acid

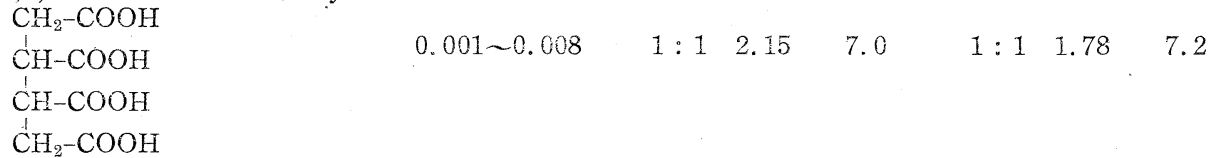

* Data in parentheses are those reported by Schubert et al. ${ }^{10)}$ for similar conditions $\left(\mu=0.16,25^{\circ} \mathrm{C}\right)$.

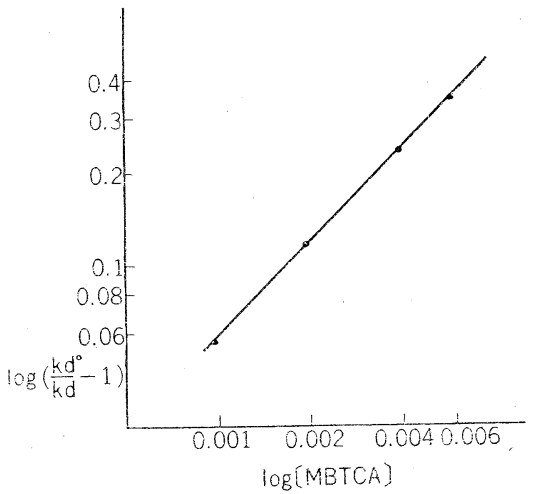

Fig. 1.

Graphical Solution of $n$

Table II. Example of Analysis of Experimental Data

\begin{tabular}{|c|c|c|c|c|c|c|c|c|}
\hline $\begin{array}{l}\text { Falsk* } \\
\text { No. }\end{array}$ & $\begin{array}{l}\text { Ion exchange } \\
\text { resin (mg.) }\end{array}$ & $\begin{array}{l}\text { Concn. of } \\
\operatorname{MBTCA}^{*} *(M)\end{array}$ & c.p.m. & /cc. & $K d$ (mg./cc.) & $\frac{K d^{0}}{K d}-1$ & $\frac{\left(K d^{0} / K d\right)-1}{[\mathrm{MBTCA}]}=K$ & $\log K$ \\
\hline $\begin{array}{l}1 \\
2\end{array}$ & $\begin{array}{l}0 \\
0\end{array}$ & $\begin{array}{l}0 \\
0\end{array}$ & $\left.\begin{array}{l}2280 \\
2273\end{array}\right\}$ & 2277 & & & & \\
\hline $\begin{array}{l}3 \\
4\end{array}$ & $\begin{array}{l}100 \\
100\end{array}$ & $\begin{array}{l}0 \\
0\end{array}$ & $\left.\begin{array}{l}657 \\
670\end{array}\right\}$ & 664 & $\begin{array}{l}1.2146 \\
\left(=K d^{0}\right)\end{array}$ & & & \\
\hline $\begin{array}{l}5 \\
6\end{array}$ & $\begin{array}{l}100 \\
100\end{array}$ & $\begin{array}{l}0.000996 \\
0.000966\end{array}$ & $\left.\begin{array}{l}700 \\
680\end{array}\right\}$ & 690 & 1.1500 & 0.05617 & 58.1 & 1.74 \\
\hline $\begin{array}{l}7 \\
8\end{array}$ & $\begin{array}{l}100 \\
100\end{array}$ & $\begin{array}{l}0.001932 \\
0.001932\end{array}$ & $\left.\begin{array}{l}730 \\
706\end{array}\right\}$ & 718 & 1.0857 & 0.11873 & 61.5 & 1.79 \\
\hline $\begin{array}{r}9 \\
10\end{array}$ & $\begin{array}{l}100 \\
100\end{array}$ & $\begin{array}{l}0.003864 \\
0.003864\end{array}$ & $\left.\begin{array}{l}771 \\
766\end{array}\right\}$ & 769 & 0.9805 & 0.23876 & 61.8 & 1.79 \\
\hline $\begin{array}{l}11 \\
12\end{array}$ & $\begin{array}{l}100 \\
100\end{array}$ & $\begin{array}{l}0.005796 \\
0.005796\end{array}$ & $\left.\begin{array}{l}815 \\
808\end{array}\right\}$ & 812 & 0.9021 & 0.34641 & 59.8 & 1.7 \\
\hline
\end{tabular}

* The volume of each solution containing same quantity of ${ }^{90} \mathrm{Sr}$ is finally adjusted to $50 \mathrm{cc}$.

** meso-1,2,3,4-Butanetetracarboxylic acid.

本研究に当り御指導御鞭撻を頂いた石館守三教授, 放射性同位元素使用の御便宜と御指導を頂いた鶴藤丞助教 授炕感謝致し宗す。招研究費の一部は文部省科学研究費によつた。

10) J. Schubert, A. Lindenvaum: J. Am. Chem. Soc. 74, 3529(1952). 